\title{
Evaluation of the autoimmune response in leprosy
}

\author{
G. KROUMPOUZOS, * A. VARELTZIDIS, * \\ M. M. KONSTADOULAKIS, $\dagger$ G. AVGERINOU,* \\ G. ANASTASIADIS, ${ }^{*}$ H. KROUBOUZOU, $\dagger$ \\ A. PANTELEOS $\ddagger$ \& A. TOSCA $\S$ \\ *Department of Dermatology, University of Athens, 'A. Sygros' \\ Hospital, 5 Dragoumi str., 16121 Athens; $\dagger$ Hippokration Hospital, \\ 114 Vas. Sophias str., 11527 Athens; $\ddagger$ Hospital of Western Attica, \\ 1 Dodekanisou str., 12241 Egaleo, Athens; and §Department of \\ Dermatology, University of Crete, 48 Vas. Sophias str., 11528 \\ Athens
}

Accepted for publication 8 January 1993

Summary Immunological responses to a panel of antigens were evaluated in 27 patients with lepromatous and 20 patients with tuberculoid leprosy and compared with 24 pulmonary tuberculosis patients, 25 systemic lupus erythematosus patients and 41 healthy blood donors. Some autoantibody specificities were extensively studied for the first time in mycobacterial infections. Striking immunoserological abnormalities were found in patients with lepromatous leprosy, particularly in those presenting with relapse.

Inhibition assays were performed, providing a tool for further analysis of the binding range of specific anti-N.D.O. BSA antibodies and strengthening the suggestion of molecular mimicry reactions between cytoskeletal proteins, host stress proteins and Mycobacterium leprae antigens or stress proteins. A significant serological overlap between lepromatous leprosy and autoimmune diseases is indicated.

\section{Introduction}

The presence of antibodies (Abs) against nucleic acids and nucleoproteins is considered to be the hallmark of systemic lupus erythematosus (SLE). Antibodies which react against several determinants have been reported, however, in a broad spectrum of autoimmune disorders and infectious diseases. ${ }^{1-3}$ In the present study, we investigated immunoserological responses to other than specific $M$. leprae antigens in patients with leprosy and re- 
analysed autoantibody specificities, in an attempt to clarify the mechanisms involved in the autoantibody production and the clinical significance of these Abs.

Special interest was given in the comparison of the autoantibody profile of leprosy with that of tuberculosis (TBC), since causative infectious agents are considered similar in structure and morphology and similar host defence mechanisms are involved, although their clinical course differs. Patients with SLE served as a control group, since SLE, a model for the study of autoimmune responses, offers the opportunity to study similar immune aberrations in chronic mycobacterial infections and autoimmune diseases.

\section{Materials and methods}

\section{PATIENTS}

Sera from 47 hansenians ( 23 men/24 women) were examined. The disease classification was: 20 with lepromatous, 14 with tuberculoid, 7 with borderline-lepromatous and 6 with borderline-tuberculoid form. For the presentation of our results, however, lepromatous and borderline-lepromatous groups are given with the term 'LL', whereas all other subgroups with 'TT'. The mean age was 60 years and the average disease and treatment duration 27 and 18 years, respectively. The Bacteriological $\left(0-6^{+}\right)$and Morphological Index $(0-100 \%)$ were calculated. ${ }^{4} \mathrm{~A}$ division in active or inactive disease followed, in accordance with clinical, histological and bacteriological data.

Control sera were obtained from (i) 24 patients with active, cavitary pulmonary TBC (mean age-54 years), whose diagnosis was based on clinical, radiological and bacteriological data; (ii) 25 SLE patients who met the revised criteria of the American Rheumatism Association; ${ }^{5}$ and (iii) 41 healthy blood donors (C).

\section{ANTIGEN-ANTIBODIES}

Native double-stranded DNA (dsDNA) from calf thymus, cardiolipin (cl) from bovine heart, human IgG, Sm/RNP, bovine actin (act) and myosin (mys), sl-nuclease, goat peroxidase-conjugated antibody specific to human $\mu$ - and $\gamma$-chain were purchased from Sigma Co. Bovine serum albumin was purchased from Serva Co. Single-stranded DNA (ssDNA) was prepared after boiling dsDNA for $10 \mathrm{~min}$ at $100^{\circ} \mathrm{C}$ and chilling in ice for 5 min. N.D.O. BSA solution was kindly provided by Dr P. Brennan and D. Chatterjee, Department of Microbiology, University of Colorado (USA).

\section{ENZYME-LINKED IMMUNOSORBENT ASSAYS}

Previous methods with minor modifications were followed. Polystyrene flat bottomed plates were coated with the following antigens: (a) dsDNA, $50 \mu \mathrm{g} / \mathrm{ml}$ in tris-buffered saline (TBS), $\mathrm{pH}=7 \cdot 4$; (b) ssDNA, $5 \mu \mathrm{g} / \mathrm{ml}$ in TBS; (c) Sm/RNP, $20 \mu \mathrm{g} / \mathrm{ml}$ in borrate buffer, $\mathrm{pH}=8.6$; (d) $\mathrm{cl}, 50 \mu \mathrm{g} / \mathrm{ml}$ in absolute ethanol; (e) act, mys, $10 \mu \mathrm{g} / \mathrm{ml}$ in carbonatebicarbonate buffer (CBC), $\mathrm{pH}=9 \cdot 6$; (f) human $\mathrm{IgG}, 50 \mu \mathrm{g} / \mathrm{ml}$ in phosphate-buffered saline (PBS); (g) N.D.O. BSA, $1: 1000$ in CBC.

For anti-dsDNA especially, a step with sl-nuclease (50 IU $/ \mathrm{ml}$ in PBS) followed. Afterwards, the patient's serum which had been diluted was added (1:600 for N.D.O. BSA, 1:200 for Sm/RNP, 1:100 for cl, act, mys, human IgG and 1:50 for ssDNA, 
dsDNA). Finally, plates were incubated for $1.5 \mathrm{hr}$ at $37^{\circ} \mathrm{C}$ with peroxidase labelled goat anti-human IgG or IgM antibody $(1: 2000$ for Sm/RNP, ssDNA, act, mys, human IgG, $1: 1000$ for cl, dsDNA, N.D.O. BSA). Pooled serum was used as the normal reference serum. Optical density (OD) readings of control wells were subtracted from test values. The value of human pool plus 3 standard deviations was estimated as the normal cut-off point.

\section{COMPETITIVE IMMUNOENZYME ASSAYS}

Inhibition fluid phase assays were performed to study the binding range of specific antiN.D.O. BSA Abs. A dilution giving 50\% of maximal binding for anti-N.D.O. BSA Abs was chosen for these assays and the test antibody was mixed with various dilutions of the inhibitor heterologous antigen $(3-300 \mu \mathrm{g} / \mathrm{ml})$ for $1 \mathrm{hr}$ at $37^{\circ} \mathrm{C}$. Single- and doublestranded DNA, Sm/RNP, actin, myosin, and cardiolipin served as inhibitors (Figures 24). The mixture was allowed to react with the immobilized antigens on the plates for $1 \mathrm{hr}$ at $37^{\circ} \mathrm{C}$. Finally, monospecific anti- $\mu$ or anti- $\gamma$ peroxidase labelled antibody was added at $1 \mu \mathrm{g} / \mathrm{ml}$. Results were expressed as percent inhibition of anti-N.D.O. BSA activity:

$$
\% \text { Inhibition }=\left(1-\frac{\text { OD with Inhibitor }- \text { Background }}{\text { OD without Inhibitor }- \text { Background }}\right) \times 100
$$

\section{Results}

Frequencies of Abs against single-stranded DNA, cardiolipin, human IgG, actin, and myosin in the groups studied are shown in Table 1. High levels of anti-ssDNA (IgG) Abs were found in LL $(37.03 \%)$ and TBC $(33 \cdot 30 \%)$, but were significantly lower, however, than in SLE (80\%, Figure 1). Anti-cl (IgM) Abs in LL (29.60\%) showed a trend to difference with TBC. SLE sera, however, contained high levels of anti-cl Abs of both isotypes (IgG $60 \cdot 10 \%$, IgM 36\%). Antibodies against human IgG (IgM isotype) were elevated in LL $(25.92 \%)$ and detected in the sera of all hansenians with relapse at the time of the study.

Antibodies against cytoskeletal proteins were detected in remarkably higher levels in LL than other groups. Anti-act (IgG) Abs in LL (57.10\%) showed difference with other

Table 1. Autoantibody frequencies (\%) in the groups studied

\begin{tabular}{|c|c|c|c|c|c|}
\hline \multirow[b]{2}{*}{ Antibodies } & \multicolumn{5}{|c|}{ Groups } \\
\hline & LL & TT & $\mathrm{TBC}$ & SLE & $\mathrm{C}$ \\
\hline Anti-ssDNA (IgG) & $37 \cdot 03$ & $20 \cdot 00$ & $33 \cdot 33$ & $80 \cdot 00$ & $7 \cdot 31$ \\
\hline Anti-ssDNA (IgM) & $7 \cdot 40$ & $10 \cdot 00$ & $8 \cdot 33$ & $44 \cdot 00$ & $4 \cdot 87$ \\
\hline Anti-cl (IgG) & $14 \cdot 81$ & 0 & $8 \cdot 33$ & $60 \cdot 00$ & $4 \cdot 87$ \\
\hline Anti-cl (IgM) & $29 \cdot 62$ & $10 \cdot 00$ & $8 \cdot 33$ & $36 \cdot 00$ & $2 \cdot 43$ \\
\hline Anti-IgG (IgM) & $25 \cdot 92$ & $10 \cdot 00$ & $8 \cdot 33$ & $20 \cdot 00$ & $2 \cdot 43$ \\
\hline Anti-ACT (IgG) & $57 \cdot 14$ & $10 \cdot 00$ & $8 \cdot 33$ & $36 \cdot 00$ & $7 \cdot 31$ \\
\hline Anti-ACT (IgM) & $38 \cdot 09$ & $10 \cdot 00$ & $16 \cdot 66$ & $24 \cdot 00$ & $2 \cdot 43$ \\
\hline Anti-mys (IgG) & $47 \cdot 61$ & 0 & $8 \cdot 33$ & $24 \cdot 00$ & $4 \cdot 87$ \\
\hline Anti-mys (IgM) & $71 \cdot 42$ & $10 \cdot 00$ & $16 \cdot 66$ & $4 \cdot 00$ & $2 \cdot 43$ \\
\hline
\end{tabular}




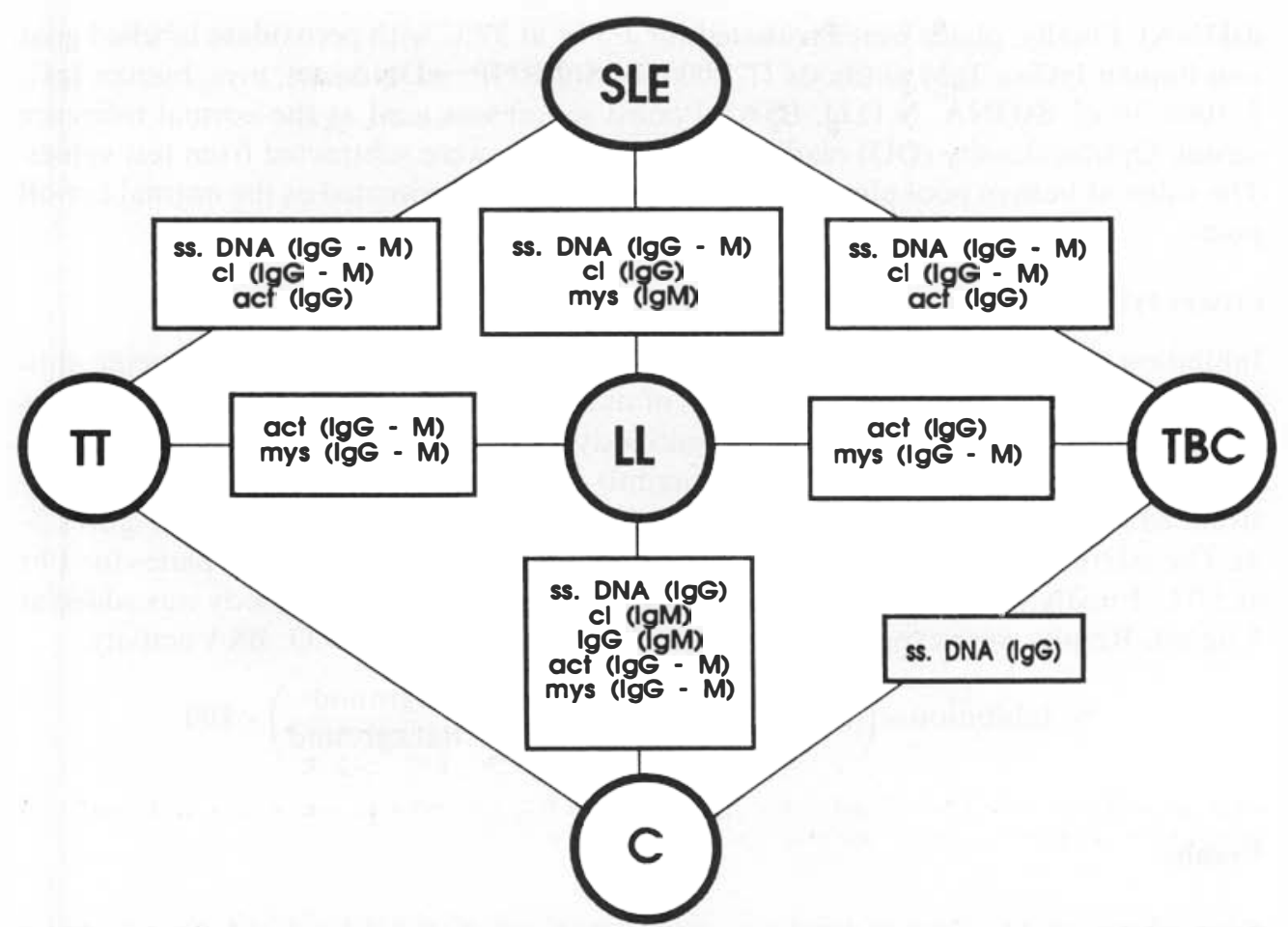

Figure 1. Significant differences $(p<0.05)$ among groups (Fisher's exact test).

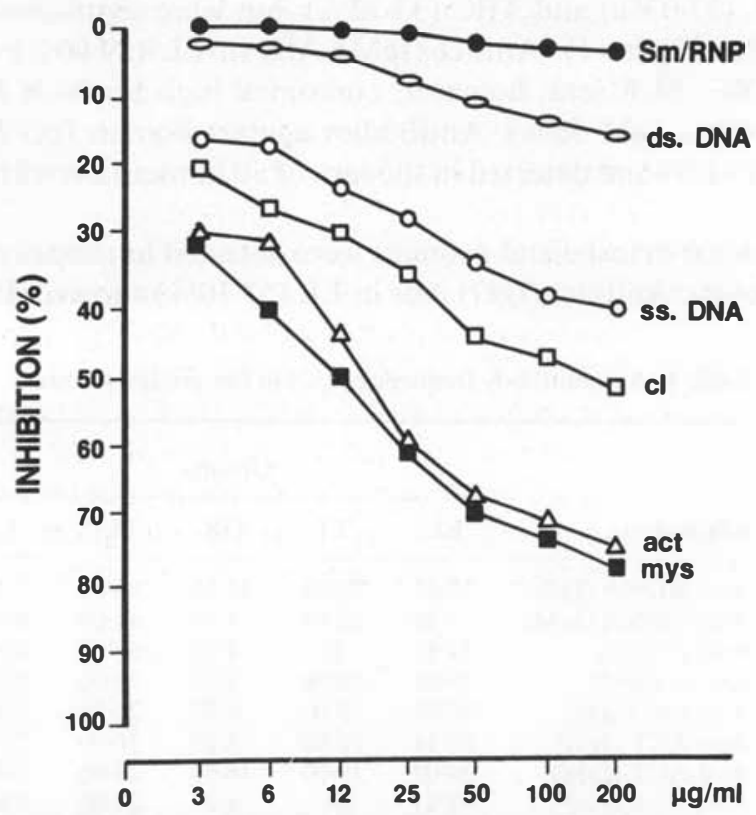

Figure 2. Inhibition of anti-N.D.O. BSA (IgM) activity of an LL serum with moderate anti-N.D.O. BSA (IgM) and high levels of anti-act (IgM), anti-mys (IgM) and anti-cl (IgM). 


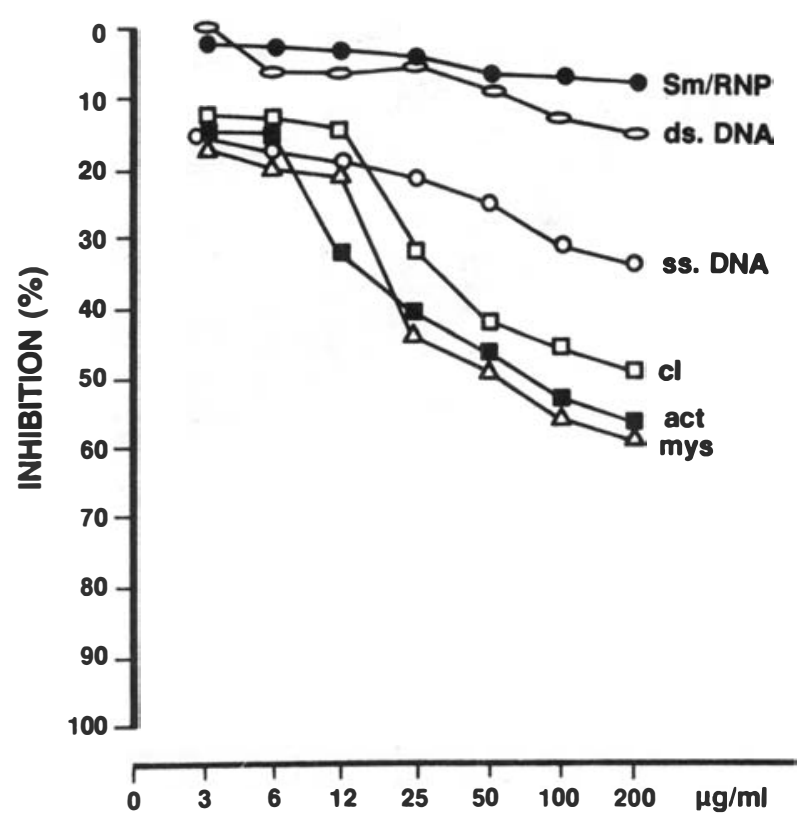

Figure 3. Inhibition of anti-N.D.O. BSA ( $\operatorname{IgM})$ activity of an LL serum with high anti-N.D.O. BSA (IgM) and moderate levels of anti-act (IgM) and anti-mys (IgM).

groups besides SLE (Figure 1) whereas anti-act (IgM) Abs in LL (38.09\%) presented a difference only with TT. Anti-mys (IgG) Abs in LL (47.60\%) showed a difference with TT, TBC, and C, whereas anti-mys (IgM) Abs in LL were detected in notably high frequency, higher than all other groups. Anti-act $(\operatorname{IgM})$ and anti-mys $(\operatorname{IgM})$ were strongly correlated with anti-N.D.O. BSA (IgM) Abs ( $p=0.039$ and 0.0017, respectively, Fisher's exact test).

Anti-N.D.O. BSA (IgM) Abs proved to be specific for LL (62.90\%) in accordance with previous reports, ${ }^{6}$ whereas anti-N.D.O. BSA ( $\left.\mathrm{IgG}\right)$ were detected in both LL $(85 \%)$ and TT (66\%). Anti-dsDNA Abs (IgG and IgM) were specific for SLE $(64 \%$ and $28 \%$ ) as well as anti-Sm/RNP (44\% and 24\%). Differences between LL and C resulted for all Abs, besides anti-ssDNA (IgM) and anti-cl (IgG) (Figure 1). The lepromatous leprosy group and TBC differed in the prevalence of anti-act (IgG) and anti-mys (IgG and IgM) Abs. No differences were verified between TT and TBC as well as between TT and C (not included in Figure 1). Differences between multibacillary and paucibacillary leprosy resulted only for Abs against cytoskeletal proteins $(p=0 \cdot 040)$. In all, 2 lepromatous leprosy sera and 1 borderline-lepromatous leprosy serum were selected for inhibition assays. Inhibition by single-stranded DNA, cardiolipin, actin, and myosin was only partial, but higher by actin and myosin. No inhibition resulted by characteristic lupus autoantigens (dsDNA, Sm/ RNP) (Figures 2-4).

\section{Discussion}

Infection with $M$. leprae induces considerable changes in the humoral immune system, which involve aberrant responses, of ten associated with autoimmune syndromes. ${ }^{7}$ 


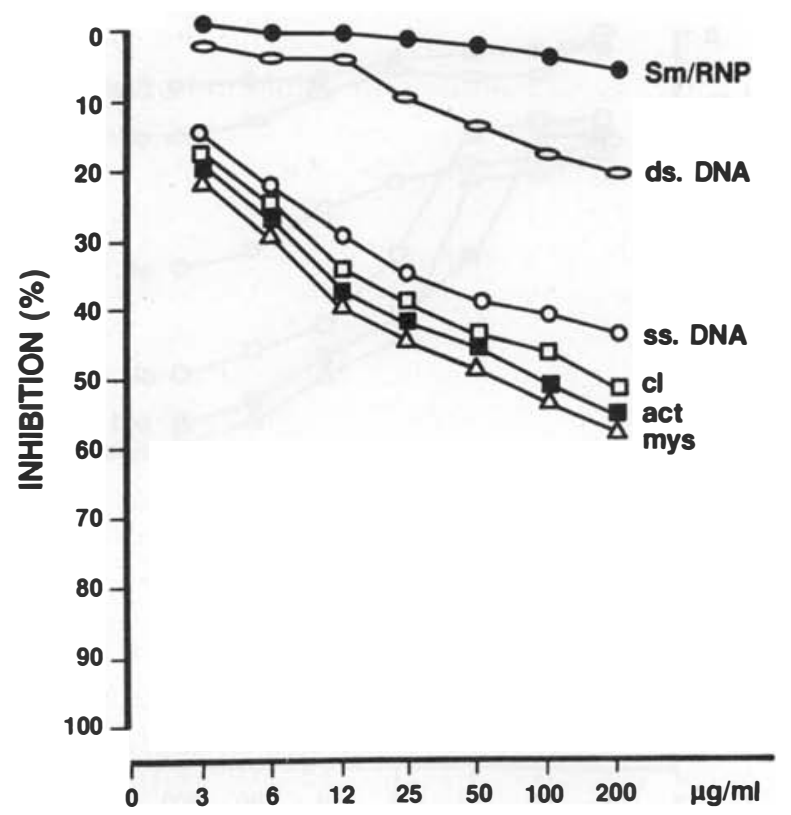

Figure 4. Inhibition of anti-N.D.O. BSA (IgG) activity of BL serum with moderate anti-N.D.O. BSA (IgG) and high levels of anti-ssDNA (IgG), anti-act (IgG), anti-mys (IgG) and anti-cl (IgG).

Autoantibodies in mycobacterial infections have been previously reported, ${ }^{7-9}$ but their origin and clinical significance have not been clarified. This stimulated us to examine a broad profile of Abs, in an attempt to further clarify the mechanisms involved in their production and their clinical associations.

Idiotypic similarities between leprosy and SLE have been hypothesized, since Mackworth-Young et al. ${ }^{10}$ have produced monoclonal Abs with highly conserved idiotypes for SLE and leprosy. Several mechanisms may account for the broad autoantibody profile in lepromatous leprosy, such as polyclonal B-cell activation, suppressor T-cell deficiency and molecular mimicry reactions between microbial and host agents, which may lead to cross-reactions, resulting in autoimmune phenomena. ${ }^{11}$

In this study, we compared the autoantibody profile of LL and TT with that of TBC and SLE. Our findings first indicate the detection of anti-ssDNA (IgG) Abs besides SLE in LL and TBC, as previously reported..$^{2,3,10}$ Some authors have suggested cross-reactions with mycobacterial DNA ${ }^{2,3,8}$ and others ${ }^{10}$ that anti-ssDNA might arise by expansion of a pool of precursors in the normal antibody repertoire, in state of polyclonal B-cell activation. The inability to detect SLE characteristic Abs probably indicates that autoimmunity is expressed in a structured fashion that cannot be attributed to a random escape from absolute control and the inducing stimuli or cellular defects in SLE are probably disease specific. ${ }^{2}$ High levels of Abs against cytoskeletal proteins were found in LL patients. There is a striking lack of information, however, concerning Abs against cytoskeletal proteins in mycobacterial infections. The prevalence of anti-act (IgG) Abs was higher in LL $(57 \cdot 10 \%)$ than all other groups-besides SLE-whereas for anti-act (IgM) Abs, difference was shown only in comparison with TT and C (Table 1, Figure 1). 
Anti-act (IgM) were positively correlated with anti-N.D.O. BSA (IgM) Abs ( $p=0.0039)$, a correlation which was further strengthened by inhibition of anti-N.D.O. BSA (IgM) activity by actin (60-70\%) (Figures 2-4). Anti-mys Abs were detected in significantly higher prevalence in LL $(47 \% \mathrm{IgG}, 71 \cdot 40 \% \mathrm{IgM})$ than in other groups (Figure 1). Antimys (IgM) were also correlated with anti-N.D.O. BSA (IgM) Abs and a partial inhibition of anti-N.D.O. BSA (IgM) Abs by myosin was recorded.

The investigation of antigens involved in the immune response against tuberculosis and leprosy bacilli led to the observation that a variety of heat shock or stress proteins (HSP 60, HSP 70) which are expressed in host cells under stress conditions, present great sequence homology with mycobacterial stress proteins ${ }^{13}$ which are considered among the immunodominant targets of both antibody and T-cell responses. ${ }^{14,15}$ Moreover, some stress proteins are known to modulate the action of cytoskeletal proteins and other protein complexes ${ }^{16}$ and this functional association may result in parallel recognition, as stress proteins are strong immunogens and are expressed in active disease. This is strengthened also by the results of the present study, as Abs against cytoskeletal proteins were mainly detected in active disease.

Differences beween multibacillary and paucibacillary disease were found only for Abs against cytoskeletal proteins, further increasing the probability that cytoskeletal proteins, this group of highly conserved proteins, are involved in molecular mimicry reactions with $M$. leprae antigens or stress proteins, another group of conserved proteins. A network of parallel recognitions or even successive cross-reactions between host stress proteins, cytoskeletal proteins and $M$. leprae antigens or stress proteins could therefore be suggested.

This hypothesis becomes more intriguing in the light of recent findings, that stress proteins may be expressed on cellular membranes, near MHC II antigens, during the antigen recognition process. ${ }^{16,17}$ Similarities between host stress proteins and $M$. leprae antigens or stress proteins, could aid the survival of $M$. leprae in avoiding the host immune response. We are a long way, however, from ascertaining this suggestion as well as the hypothesis of some authors, ${ }^{18}$ that recognition of sequences unique in mycobacterial stress proteins could lead to immunity, whereas recognition of common sequences in human and mycobacterial stress proteins could trigger autoimmunity.

From the comparison of the autoantibody profile in the groups studied, we found that LL differs significantly from TT and TBC, mainly as regards Abs against cytoskeletal proteins, while it possesses an intermediate position between TT, TBC and SLE, as regards other autoantibodies. Previous suggestions ${ }^{8}$, that generalized humoral immunoserological abnormalities in LL are only remote sequellae of the disease, due to its chronic nature, are in dispute, since (a) striking differences in the autoantibody profile between LL and TT, TBC were shown, although minor divergences in mean disease duration and patient age were recorded; (b) autoantibody levels were correlated neither with disease and treatment duration nor with patient age; and (c) some responses were associated with active LL, assuming in this way clinical significance. Further studies will have to be done to verify the role of heat shock proteins in mycobacterial infections.

\section{Acknowledgments}

We wish to thank Dr P. Brennan and D. Chatterjee, Department of Microbiology, 
University of Colorado, who kindly provided us with the N.D.O. BSA antigen preparation.

\section{References}

1 Shoenfeld Y, Schwartz RS. Immunologic and genetic factors in autoimmune diseases. $N$ Engl J Med, 1984; 311: 1019-29.

2 Bonfa E, Llovert R, Scheinberg M, De Souza JM, Elkon KB. Comparison between autoantibodies in malaria and leprosy with lupus. Clin exp Imm, 1987; 70: 529-37.

3 Sela O, El-Roeing A, Isenberg DA, Kenedy RC, Colaco CB, Pinkhas J, Shoenfeld Y. A common anti-DNA idiotype in sera of patients with active pulmonary tuberculosis. Arthritis Rheum, 1987; 30: 50-6.

${ }^{4}$ Ridley DS, Jopling WH. Classification of leprosy according to immunity, a five-group system. Int J Lepr, 1966; 34: 255-73.

5 Tan EM, Cohen AS, Fries JF et al. The 1982 revised criteria for the classification of systemic lupus erythematosus. Arthritis Rheum, 1982; 25: 1271-7.

6 Young DB, Dissanayake S, Miller RA, Khanolkar SR, Buchanan TM. Humans respond predominantly with IgM immunoglobulin to the species specific glycolipid of Mycobacterium leprae. J Infect Dis, 1984; 149: 8703.

7 Rawlinson WD, Basten A, Hargrave JC. Clinical significance of changes in serum proteins, immunoglobulins and autoantibodies in leprosy. Int J Lepr, 1987; 55: 277-85.

8 Rea TH, Quismorio FP, Harding B. Immunologic responses in patients with lepromatous leprosy. Arch Dermatol, 1976; 112: 791-800.

9 Turk JL, Bryceson ADM. Immunological phnomena in leprosy and related diseases. Adv Immunol, 1971; 13: 209-66.

10 Mackworth-Young C, Sabbaga G, Schwartz RS. Idiotypic markers of polyclonal B-cell activation. J Clin Invest, 1987; 79: 572-81.

11 Oldstone MBA. Molecular mimicry and autoimmune disease. Cell, 1989; 50: 819-20.

12 Furukawa F, Kashihara M, Imamura S, Ohshio G, Hamashima Y. Evaluation of anti-cardiolipin antibody and its cross-reactivity in sera of patients with lepromatous leprosy. Arch Dermatol, 1986; 278: 317-19.

13 Young RA, Elliot TJ. Stress proteins, infection and immune surveillance. Cell, 1989; 59: 5-8.

14 Watson JD. Leprosy: understanding protective immunity. Immunol Today, 1989; 10: $218-21$.

15 Lewin R. Stress proteins: are links in disease. Science, 1988, 240: 1732-3.

16 Kaufmann SHE. Heat shock proteins and the immune response. Immunol Today, 1990; 11: 129-35.

17 Born W, Happ MP, Dallas A, Reardon C, Kubo R, Shinnick T, Brennan P, O'Brien R. Recognition of heat shock proteins and $\gamma \delta$ cell function. Immunol Today, 1990; 11: 40-3.

18 Cohen IR. An eclectic summary of the symposium on autoimmunity. Immunol Today, 1989; 10: 394-5. 


\title{
Évaluation de la réponse auto-immune dans la lèpre
}

\author{
G. Kroumpouzous, A. Vareltzidis, M. Konstadoulakis, G. Avgerinou, \\ G. Anastasiadis, H. Kroubouzou, A. Panteleos et A. Tosca
}

Résumé Les réponses immunologiques à une série d'antigènes ont été évaluées dans 27 cas de lèpre lépromateuse et 20 de lèpre tuberculoïde et comparées à 24 cas de tuberculose pulmonaire, 25 cas de lupus érythémateux systémique et aux réponses de 41 donneurs de sang sains. Certaines de ces spécificités autoanticorps étaient étudiées extensivement pour la premièref ois dans les infections mycobactériennes. Nous avons observé des anomalies immuno-sérologiques frappantes chez des patients atteints de lèpre lépromateuse, en particulier chez ceux qui ont rechuté.

Des tests d'inhibition ont été effectués, qui faciliteront l'analyse plus poussée du spectre de réactivité des anticorps spécifiques anti-N.D.O. ASB et aideront à prouver la suggestion de l'éxistence de réactions de mimétisme moléculaire entre les proteines cyto-squelettiques, les proteines de stress de l'hôte et les antigènes de Mycobacterium leprae ou les proteines de stress. On a observé un chevauchement sérologique significatif entre la lèpre lépromateuse et les maladies auto-immunes.

\section{Evaluación de la respuesta autoinmuna en la lepra}

\author{
G. Kroumpouzous, A. Vareltzidis, M. Konstadoulakis, G. Avgerinou, \\ G. Anastasiadis, H. Kroubouzou, A. Panteleos y A. Tosca
}

Resumen En 27 pacientes con lepra lepromatosa y 20 con lepra tuberculoide, se evaluaron las respuestas inmunológicas a una selección de antigenos, y se compararon con 24 pacientes con tuberculosis pulmonar, 25 con lupus eritematoso sistémico y 41 donantes de sangre sanos. Se estudiaron extensamente algunas de las especificidades de autoanticuerpo por primera vez en las infecciones micobacterianas. Se descubrieron anormalidades inmunoserológicas impresionantes en los pacientes con lepra lepromatosa, especialmente en los casos de recaída.

Se realizaron ensayos de inhibición, resultando en una herramienta para un análisis adicional de los anticuerpos específicos anti-N.D.O. BSA, reforzando la posibilidad de reacciones miméticas moleculares entre las proteínas citoesqueletales, las proteínas producidas por estrés en el huésped, y antigenos de Mycobacterium leprae o proteínas del estrés. Los resultados indican una coincidencia serológica significativa entre la lepra lepromatosa y las enfermedades autoinmunas. 